ECONOMICS

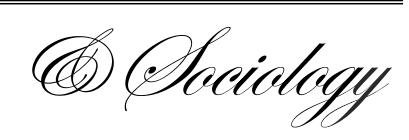

\title{
RETURNED MIGRANTS AND REMITTANCES ALLEVIATING POVERTY: EVIDENCE FROM MALANG, EAST JAVA
}

\author{
Devanto Shasta Pratomo, \\ Brawijaya University, \\ Malang, Indonesia, \\ E-mail:dede_gsu02@yaboo.com \\ Kankesu Jayanthakumaran, \\ University of Wollongong, \\ Wollongong, Australia, \\ E-mail:kankesu@uow.edu.au
}

Received: September, 2017 1st Revision: December, 2017 Accepted: February, 2018

DOI: $10.14254 / 2071-$ 789X.2018/11-1/13

JEL Classification: I32, J61

\begin{abstract}
This paper examines the sustainability of returning international migrants, who remain at home country, moving out from poverty. This study uses cross-sectional primary data as of September and October 2015 on 840 households of the returned migrants which is around $10 \%$ of the overall migrant stock in the Malang district, East Java as of 2014/2015; and also 840 current migrants, which is again around $10 \%$ of the current migrant stock as a control group. Although we have found that remittances reduce the probability of households living in poverty, this study concludes that returning migrants will not be better off for very long, and will almost certainly return to poverty after some time. The major limitation of this paper is that it focuses only on the financial capital's contribution to the welfare of the returning migrants, not incorporating also such factors as human capital, business skills, or attitude that migrants get from staying overseas. The study suggests the government should provide guidance to migrant households on how to use their gained income in a more sustainable and productive way, thus making the best of the financial capital available to them.
\end{abstract}

Keywords: poverty; return migrants; remittances, Malang, East Java, probit analysis.

\section{Introduction}

Benefits and costs of return migration in developing countries require more scrutiny because the benefits of new ideas, business skills, accumulated savings and assets from the employment abroad contribute to the development of home countries ${ }^{1}$. Migrants planning to return therefore tend to maintain connections with their home country and send back remittances to improve the living conditions of their relatives and friends, but not all returnees are able to improve these households' welfare because the financial capital gained is not used in a sustainable manner (Adams and Cuecuecha, 2010).

There are two reasons for the research gap in this area: many people perceive international migration to be a one-way movement, and there is not enough data on return

\footnotetext{
${ }^{1}$ Returned migrants are defined here as the members of households that were previously serving as migrants but who have now returned to their home country with no intention to go overseas again.
} 
migration for macroeconomic assessments (Wahba, 2015). Although there are some studies on the role of remittances in European countries (Leon-Ledesma and Piracha, 2001; Schiopu and Siegfried, 2006; Grigorian and Melkonyan, 2011, and many more), only a few studies focused on the remittances and using the microlevel survey data on the ASEAN countries (Parinduri and Thangavelu, 2011; Nguyen and Purnamasari, 2011) failed to capture the fate of return migrants in this region. Given that many countries worldwide tend to recognise international work contracts and labour migration, return migration today becomes an important phenomenon in the world and in the ASEAN region in particular, so the home countries should enact the policies to capture their skills, knowledge, and savings for the aims of further alleviation of poverty.

Although international labour migration is an important issue for alleviating poverty in Indonesia, almost no attention has been given to empirically analysing the issue of alleviating poverty at its origin. This is mostly due to the scarcity of data resulting from no nationally representative household survey covering information, inter alia, on labour migrants, including those that returned. Moreover, the data published by the government is also very much biased towards low-skilled workers and is highly inaccurate due to high proportion of undocumented labour migrants and also those who are returning and leaving several times (Bachtiar, 2011). The previous empirical studies on the effects that international labour migration has on poverty used the Indonesian Family Life Survey (IFLS) data, but the IFLS does not contain specific questions on the history of migration and remittances (Adams and Cuecuecha, 2010; Parinduri and Thangavelu, 2011). The history of individual migrants would help in assessing the sustainability because remittances and savings improve the quality of life for return migrants.

This study, therefore, focuses on the primary data obtained from our own survey carried out in the Malang district, East Java so that to examine the sustainability of returning migrants over time and how their overall remittances affected the financial condition of the related households ${ }^{2}$. The previous empirical studies on migration and remittances in Indonesia (such as Parinduri and Thangavelu, 2011) used the present condition of current migrant households and migration status as a proxy for remittances but not the value or magnitude of the remittances.

The remainder of this paper is organised as follows. The second section reviews the nexus between international migration, remittances, and poverty. The third section discusses the data and the methodology used in this paper and then provides empirical results on the poverty status of return migrant households in the fourth section. The final section provides conclusions along with implications.

\section{Literature Review}

International labour migration has become an important component of the Indonesian economy, to the extent that the number of migrants from Indonesia who work overseas is approaching 7 million in 2015 (or about 5 percent of the labour force), in terms of stock, making it one of the largest sources of labour migrants in Asia, following Sri Lanka and the Philippines (Hugo, 2002). In fact, migration is supported by the government as a development strategy to reduce unemployment and to the level of poverty at its origin. Most migrants overseas are domestic workers in the informal sectors, although some are employed in the construction, manufacturing, and farming sectors. Their primary destinations include neighbouring countries, such as Malaysia and Singapore, East Asian countries such as

\footnotetext{
${ }^{2}$ A migrant household here is the household that has as a member who is either a current migrant or a returned migrant.
} 
Hongkong and Taiwan, and Middle Eastern countries such as Saudi Arabia, the United Arab Emirates, and Qatar. Table 1 provides the data of registered Indonesian labour migrant flows by destination. There is a significant drop in the recent years related with the moratorium policy from Indonesian government due to some cases of human right violation and exploitation of female domestic workers (Raharto, 2011).

Table 1. Indonesian Labor Migrant Flows by Destination, 2012-16

\begin{tabular}{lccccc}
\hline & 2012 & 2013 & 2014 & 2015 & 2016 \\
\hline Malaysia & 134,088 & 150,248 & 127,812 & 97,261 & 87,616 \\
\hline Taiwan & 81,071 & 83,544 & 82,665 & 75,304 & 77,087 \\
\hline Saudi Arabia & 40,655 & 45,394 & 44,325 & 23,000 & 13,538 \\
\hline Hongkong & 45,478 & 41,769 & 35,050 & 15,322 & 14,434 \\
\hline Singapore & 41,556 & 34,655 & 31,680 & 20,895 & 17,700 \\
\hline United Arab Emirates & 35,888 & 44,505 & 17,963 & 7,619 & 2,575 \\
\hline Brunei Darussalam & 13,146 & 11,269 & 11,616 & 9,993 & 8,152 \\
\hline Qatar & 20,380 & 16,237 & 7,862 & 2,460 & 1,355 \\
\hline South Korea & 13,593 & 15,374 & 11,849 & 5,501 & 5,912 \\
\hline United States & 15,353 & 15,021 & 9,233 & 1,029 & 249 \\
\hline Others & 53,401 & 54,152 & 49,817 & 17,352 & 5833 \\
\hline Total & 494,609 & 512,168 & 429,872 & 275,736 & 234,451 \\
\hline
\end{tabular}

Source: BPS (2017).

Most Indonesian labour migrants come from rural areas that are usually characterized by subsistence agriculture, high underemployment, a surplus of low-skilled labour, and widespread poverty (Nguyen and Purnamasari, 2011 and Syafitri and Knerr, 2012). There has been significant growth in educational attainment through government policy of compulsory 9-years basic education which has also encouraged rural communities to seek better employment prospects than dissatisfying subsistence agriculture and uncertain income at home (Hugo, 1995), thus making international labour migration a significant option.

This increase in labour migration from Indonesia has contributed to an increase in remittance flows (Figure 1). Nguyen and Purnamasari (2011) indicated that about 17 percent of the total remittances of labour migrants flow back to the East Asia and Pacific region, including Indonesia. In fact, Indonesia is the fourth highest remittance receiving country in Asia after India, China, and the Philippines, with total remittances of about US\$ 9 million in 2017 and around US\$ 4 million remittances from Saudi Arabia (see Figure 1)). At the local level, remittances sent by international labour migrants provide significant revenues for villages in Indonesia and play an important role in improving the living standards of households. Indeed, in some districts in East Java and West Nusa Tenggara, the total remittances sent by migrant workers are even higher than their regional own-source revenues (World Bank, 2006). 


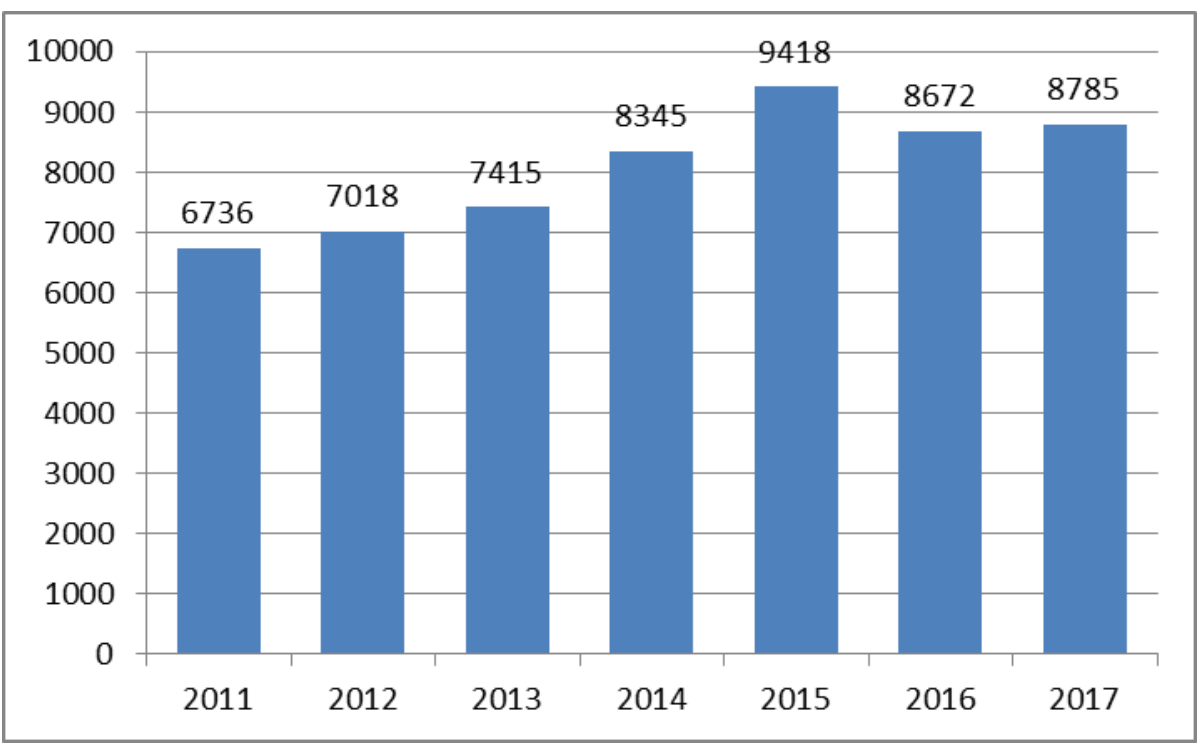

Figure 1. Total Registered Remittances Sent by Indonesian Migrant Workers, 2011-17 (Million of USD)

Source: BPS (2017).

The utilization of remittances at their origin varies because as Adams and Cuecuecha (2010) and the World Bank (2006) mention, the remittances for Indonesian labour migrant households are mostly used to improve their consumption of basic goods or food items. In fact, Adams and Cuecuecha (2010) argue that households in Indonesia receiving remittances are generally poorer than other households, making it difficult to devote more of their expenditures to investment in human and physical capital. Parinduri and Thangavelu (2010) also found little evidence of the impact of remittances on investment in education and health, and only a few invested their remittances in a business venture or managed it in a sustainable manner (World Bank, 2006).

The paper by Adams and Cuecuecha (2010) is a pioneering empirical study on the nexus of international migration, remittances, and poverty in Indonesia. The authors used instrumental variables and found that international remittances have a large significant effect on reducing poverty, that is, households receiving international remittances experienced a decline in the poverty headcount by $26.7 \%$ and a decline in the squared poverty gap by $69.9 \%$, with a counterfactual situation with households without international remittances. Interestingly, unlike other countries (see Adams and Cuecuecha, 2010 in Guatemala), households in Indonesia receiving international remittances are much poorer and therefore focus on improving their consumption of basic goods rather than invest in human and physical goods. For instance, households in Guatemala receiving international remittances received more than 10 times their annual income per capita from remittances than those in Indonesia.

With the nexus of international migration, remittances, and poverty of developing countries, Adams and Page (2005) concluded that migration and remittances definitely help to reduce poverty in the sending and developing countries. Using data from 71 developing countries, the authors showed that international migration reduces the level, depth, and severity of poverty at its origin. Specifically, a $10 \%$ increase in the share of international migrants will reduce the share of people living on poverty by $2.1 \%$, while a $10 \%$ increase in per capita official international remittances will decrease the share of people living in poverty by $3.5 \%$. Besides Adams and Page (2005), there are several studies in specific regions, these 
include Acosta et al. (2008) in Latin America and the Carribean, Gupta et al. (2009) in Subsaharan Africa, Adams et al. (2008) in Ghana, Yang and Martinez (2005) in Philippines, and Adams and Cuecuecha (2010) in Indonesia; all of whom agree that migration and remittances have a statistically significant effect on reducing poverty. Barham and Boucher (1998), Yang and Martines (2005), and Acosta et al. (2008) also extended their analysis by examining the impact of remittances on income inequality. The results varied because Acosta et al. (2008) found a small negative effect on inequality and Barham and Boucher (1998) found an increase in income inequality when compared with the no-migration households.

With regards to Indonesia, Parinduri and Thangavelu (2011), and Nguyen and Purnamasari (2011) extended their analysis by looking at the impact that international migration and remittances of Indonesian migrants had on the welfare of their children, as measured by the schooling and labour supply. According to Parinduri and Thangavelu (2011), international migration tends to have a negative impact on the human accumulation of the child, as indicated by a decrease in the quality of schooling for the children, whereas Nguyen and Purnamasari (2011) found that migration does not seem to affect school enrollment or attendance of children significantly, suggesting that an absent parent had a negative effect.

All of these studies focused on the present condition of migrant households, there is almost no evidence that the sustainability of Indonesian return migrant households has been examined over time. Using a survey in Ponorogo-East Java, Yen et al. (2014) found that international current migrant households are more likely to report a greater improvement of their quality of life compared to five years before the survey, but there is no significant difference in terms of relative living conditions compared to five years before the survey. Regarding the condition of return migrant households, the World Bank (2006) surveyed that the remittances of Indonesian migrants that are mostly used for basic needs will usually be exhausted within 2-7 months, after which these households either revert to their original condition or work overseas again.

\section{Data and Methodology}

The objective of this study, firstly, is to examine the potential movement of migrant households, by examining the condition of return migrants who remain at home country after migration with the intention of remaining in the home country. This study, therefore, investigates whether return migrants can escape from poverty forever or whether they tend to become poor again (i.e., return to their original condition) after remaining at home for a period of time. We expect that the savings and financial capital brought home by returning migrants will be exhausted within a period of time because they are more likely to be used to meet various living necessities (not a productive utilisation). This expectation is consistent with World Bank's (2006) prediction that return migrant will move back into poverty after 27 months.

Secondly, this study examines how the remittances of current overseas migrants affect the probability of their households moving out of poverty ${ }^{3}$. The current migrants are used as a control assuming that current migrants are likely to be the returned migrant in the future. As mentioned above, many studies indicate that the most direct link between migration and a reduction in poverty is via remittances, so this study, therefore, predicts that higher remittances will improve the welfare of households at their origin, as measured by the poverty status.

Unlike previous studies, this study uses primary data collected from a survey carried out in the Malang district in East Java. Malang consists of 33 sub-districts with a total

\footnotetext{
${ }^{3}$ Current migrant is a member of a household in home country who is currently working abroad.
} 
population of almost 3 million in 2015. The economy is supported by a manufacturing sector which contributes around 30\% to the Gross Regional Domestic Product, and an agricultural sector that contributes almost $50 \%$ of employment. The limited opportunities and lack of diversity in the industry and other modern sectors partly account for the high labour migration overseas from Malang. The poverty level in Malang is also quite high at $11.67 \%$ in 2014 , which is slightly below the national average of $12.36 \%$, while the unemployment rate is $4.83 \%$ in 2014.

This study uses cross-sectional primary data for September and October 2015 in Malang district. Recently, Malang is well known as one of the main sources of labour migrants from Indonesia, ranking 10th out of more than 500 districts, sending more than 8,000 registered labour migrants overseas in 2017 (BNP2TKI, 2018). The sample used in the study has two categories, return migrant households as primary analysis and current migrant households as a control group, each of which has 840 households, which each represents around 10\% of migrants stock from Malang flowing overseas in 2014/2015 (BNP2TKI, $2013)^{4}$. The proportional area sampling strategy used in this study is based on the number of migrants that left each sub-district in Malang in 2015. Since the unit of observation is migrant households, the survey is conducted with the return migrant and the head of household (or their representative if the head of a household is a current migrant). The survey covers characteristics such as work activities, expenditure patterns, demographic aspects and migrant characteristics that include the time migrants remain overseas, the time they remain at home, and the value and utilisation of their remittances.

With regards to method, this study focuses on return migrants by examining the household conditions of return migrants after they moved back to their origin in Malang. In this case, returned migrants are defined as a member of a household that was previously serving as a migrant but who has now returned to Malang to his/her original household. This study focuses on the duration returned migrants remained at home to see whether they are able to leave poverty for long-term or whether they tend to move back to poverty after a period of time. This study might predict that returned migrant households, a household that has as a member of a returned migrant will move back into poverty, particularly if their household does not have very much productive and investment activity. This prediction is also supported by Adams and Cuecuecha (2010) showing that the main utilisation of remittances and income obtained overseas is mainly for consumption purposes.

To determine this probability of these households moving out poverty, a probit model is estimated using a maximum likelihood method. The dependent variable is, therefore, the poverty status where return migrant households are categorised as poor or non-poor based on the definition of poverty constructed by the Indonesian Central Bureau of Statistics for the Malang district ${ }^{5}$. Poverty status of households has been estimated by accommodating all households in the sample. Returned migrants were at home at the time of the survey and their income was taken into account. The poverty status is determined at the same time for all return migrant households in the sample; i.e. during the survey conducted in 2015. The return migrant households are categorized as poor $(\mathrm{Y}=1)$ if their current (sometime after migrant returns to the origin) expenditure is below the Malang's poverty line during the survey, and non-poor $(\mathrm{Y}=0)$ if their expenditure is at or above the poverty line. The same procedure has been applied to current migrant as a control.

\footnotetext{
${ }^{4}$ In the case of multiple characteristics where a household consists of current and return migrants, it is then classified to the lesser migration category where a specific sub-district is found.

${ }^{5}$ Based on the Central Bureau of Statistics, poverty status is defined whether per capita expenditure of migrant households below or above the poverty line of Malang district. In 2015, the poverty line of Malang is IDR.254,380.- The per capita expenditure calculation follows the National Socio-Economic Survey (SUSENAS) module.
} 
The main independent variable used in this estimate is the length of time that return migrants stay at home (Malang district) after working overseas. This variable helps to determine the sustainability of return migrants moving out from poverty over time. The duration squared is added to capture a potential non-linear relationship. Some control variables are also added, including the duration that return migrants lived overseas, the total amount of money brought back to the origin after working overseas, the present activity of return migrants, the utilisation of their remittances, their country of destination, and some interactions between certain variables.

Table 2 presents the summary statistics of variables used to estimate the poverty status of return migrant households. As indicated in table 2, the proportion of poor households among return migrant households is quite large at $37.86 \%$, which is above the average poverty level of Malang district. This condition implies there is no guarantee that return migrants will automatically move out from poverty because it probably depends on how long a migrant has lived overseas and how the financial capital and savings gained overseas is utilised. On average, our return migrants sample remains at 6.6 years at home after migration, while on average they stay overseas for 6.7 years. Remittances are mostly utilised for consumption (42.8\%), including food and basic needs consumption, paying debts, and others and only $0.6 \%$ is used in a productive manner, including physical and human investments.

Table 2. Descriptive Statistics of Return Migrant Estimate

\begin{tabular}{lcccc}
\hline \multicolumn{1}{c}{ Variable } & Mean & Std. Dev. & Min & Max \\
\hline Migrant Characteristics & & & & \\
\hline Poor Households & 0.378571 & 0.48532 & 0 & 1 \\
\hline Duration living at home (after migration) & 6.589286 & 6.09747 & 1 & 33 \\
\hline Duration living at home squared & 80.55357 & 126.2953 & 1 & 1089 \\
\hline Duration living overseas & 6.741616 & 5.280257 & 0.069167 & 31 \\
\hline Duration living overseas squared & 73.29731 & 127.9044 & 0.004784 & 961 \\
\hline ln Income Overseas & 14.8218 & 0.863965 & 11.69525 & 17.03439 \\
\hline Country: Saudi Arabia & 0.339286 & 0.473749 & 0 & 1 \\
\hline Country: Hongkong & 0.317857 & 0.465921 & 0 & 1 \\
\hline Country: Malaysia & 0.153571 & 0.360752 & 0 & 1 \\
\hline Remittance Utilisation: Consumption & 0.475000 & 0.499672 & 0 & 1 \\
\hline Females & 0.775000 & 0.417831 & 0 & 1 \\
\hline Household Characteristics & & & & \\
\hline Age of HH Head & 39.3 & 9.450732 & 20 & 68 \\
\hline HH Head Work in Agriculture & 0.328571 & 0.469974 & 0 & 1 \\
\hline HH Head Work in Small Business & 0.278571 & 0.448563 & 0 & 1 \\
\hline No of dependence & 0.975 & 0.834645 & 0 & 5 \\
\hline
\end{tabular}

\section{Source: Computed.}

This study extends the analysis by examining the effect of remittances sent by current migrants on the probability of current migrant households moving out of poverty. As mentioned above, current migrants are particularly used as a control, assuming they will be returned migrants in the future. Similar to the first estimate, a probit model is estimated to see whether the current migrant household is categorized as a poor or non-poor household. Therefore, the dependent variable is whether return migrant households are categorized as poor $(\mathrm{Y}=1)$ or non-poor $(\mathrm{Y}=0)$. The main independent variables used include the total value of yearly remittances sent by a current migrant to their household and the duration that current migrants remain overseas. As mentioned above, we might predict that higher remittances sent 
by a migrant and longer period living overseas, means that the probability of their household being under the poverty line will be lower. The other independent variables consist of current characteristics such as age, gender, country of destination, occupational status overseas, and household characteristics including the age, education, and occupational status of the head of a household.

\section{Empirical Results}

Table 3 presents the estimates for the poverty status of return migrants. The dependent variable is, therefore, a binary describing whether a return migrant household is categorised as poor or non-poor based on the poverty status defined by Central Bureau of Statistics. Table 3 presents two results, one with interaction effects and one without interaction effects. The main focus of this variable explaining the poverty status of return migrants is the time they stay at home after working overseas. The pseudo $\mathrm{R}^{2}$ tend to be low as the requirement for this is usually lower for cross sectional data than time series or panel data and no obvious criterion for choosing which pseudo $\mathrm{R}^{2}$ is the adequate one (Veall and Zimmermann, 1996).

In general, the finding shows that the return migrants remain at home has a significant effect on their poverty status, and interestingly, this has a non-linear relationship, as mentioned by the duration squared variable. A non-linear relationship means that in the beginning, a migrant's household will benefit from the income and other financial capital received from working overseas, as indicated by a decrease in the probability of their households living in poverty, but after a period of time migrant households tend to return to poverty, as indicated by a positive effect in the duration square variable.

This result suggests that return migrants will not escape from poverty forever because the financial capital by labour migrant households is mainly used for their consumption (Adams and Cuecuecha, 2010 and World Bank, 2006). This is supported by the income utilisation variables presented in Table 2, which shows that if their main use of financial capital is for consumption purposes then the likelihood of their households being trapped in poverty has increased. The result is also supported by the negative interaction between duration living in the origin and the consumption utilization, indicating that the longer return migrants stay at home, while the most of their financial capital for consumption, they then will move back to poverty. This is also consistent with the findings from SMERU (2015) suggesting that without adequate management, those savings and gains in income from overseas will not have a significant impact on family welfare, and therefore the poverty cycle will continue.

Although the time which returning migrants stay at home afterwards is significant, the time they stayed overseas is not significant. This finding suggests that the longer migrants stay overseas does not guarantee that their families will move out from poverty, whereas income received overseas does, as indicated by the significant effect of the overseas income variable. In other words, the result suggests that the longer migrants stay overseas do not always associated with higher financial capital, as it depends on the utilization and country of destination. Comparing to the gender, households with female return migrants are generally less likely to be categorized as poor, but the positive interaction effect between females and Saudi Arabia shows the opposite. The result is also possibly caused by the lower income and saving offered by the country compared to East Asian countries. 
Table 3. Poverty Status among Return Migrants ( $\mathrm{Y}=1$ Poor; $\mathrm{Y}=0$ Non-Poor)

\begin{tabular}{|c|c|c|c|c|}
\hline & Coefficient & $P$ value & Coefficient & $\mathrm{P}$ value \\
\hline Duration living at home (after migration) & -0.058 & 0.012 & -0.089 & 0.000 \\
\hline Duration living at home squared & 0.002 & 0.068 & 0.002 & 0.075 \\
\hline Duration living overseas & 0.009 & 0.758 & 0.045 & 0.819 \\
\hline Duration living overseas squared & 0.000 & 0.934 & 0.001 & 0.663 \\
\hline Ln Income Overseas & -0.492 & 0.000 & -0.360 & 0.012 \\
\hline Country: Saudi Arabia & -0.480 & 0.002 & -0.292 & 0.084 \\
\hline Country: Hongkong & 0.007 & 0.957 & 0.060 & 0.669 \\
\hline Country: Malaysia & -0.300 & 0.066 & -0.556 & 0.010 \\
\hline Remittance Utilisation: Consumption & 0.337 & 0.001 & 5.963 & 0.008 \\
\hline Females & -0.212 & 0.117 & -0.441 & 0.037 \\
\hline \multicolumn{5}{|l|}{ Household Characteristics: } \\
\hline Age of HH Head & 0.004 & 0.494 & 0.007 & 0.268 \\
\hline HH Head Work in Agriculture & 0.354 & 0.001 & 0.304 & 0.004 \\
\hline HH Head Work in Small Business & -0.264 & 0.018 & -0.224 & 0.052 \\
\hline No. of dependence & 0.348 & 0.000 & 0.328 & 0.000 \\
\hline \multicolumn{5}{|l|}{ Interaction Effect } \\
\hline Females $*$ Malaysia & & & -0.239 & 0.458 \\
\hline Females * Saudi Arabia & & & 0.704 & 0.027 \\
\hline Ln Income Overseas * Consumption & & & -0.401 & 0.006 \\
\hline Duration living in the origin $*$ Consumption & & & 0.049 & 0.016 \\
\hline Duration living overseas $*$ Ln Income Overseas & & & -0.004 & 0.774 \\
\hline Constant & 6.556 & 0.000 & 4.762 & 0.031 \\
\hline No. of Obs. & 840 & & 840 & \\
\hline LR chi2 & 133.37 & & 164.6 & \\
\hline Prob > chi2 & 0 & & 0 & \\
\hline Pseudo R2 & 0.1197 & & 0.1477 & \\
\hline
\end{tabular}

Source: Computed.

Moreover, interestingly, if the head of a household works in the agriculture sector, their household tends to be categorised as poor, but if their household has a small business they tend to be categorised as non-poor. The number of the dependent is also positive and significant, suggesting that more dependents mean that households are more likely to be categorised as poor.

Table 4 presents the effect of remittances on the poverty status of current migrant households using a probit model. As mentioned before, a current migrant household is estimated as a control for return migrant households. Like the first estimate, the dependent variable used is a binary estimate where a current migrant household is categorised as poor or non-poor based on a definition by the Central Bureau of Statistics using per capita household expenditure.

As presented in Table 4, the log of total remittances sent per year to households at the origin is significant and negatively related to the poverty status, suggesting that higher remittances sent to their origin significantly reduce the probability of current migrant households living in poverty at home. This finding supports previous studies in cases of developing countries by Adams and Page (2005) and Adams and Cuecuecha (2010), showing that international remittances definitely helps to reduce poverty, particularly for migrant families at their point of origin. Although remittances have a significant effect, the time that current migrants remain overseas does not significantly influence the poverty status of current 
migrant households. Similar with the case of returned migrants, this finding suggests that the longer current migrants remain overseas does not guarantee that their families escape from poverty, but the value of their remittance does.

Another important characteristic influencing current migrants poverty status is the type of occupation practised overseas. Current migrants who work as domestic workers are more likely to find it more difficult to leave poverty than other types of occupation. This is possible because domestic workers are paid less than other occupations such as works in the industrial sector or formal sector. Moreover, most domestic sector workers are unskilled female workers with low levels of education.

Table 4. Poverty Status among Current Migrants ( $Y=1$ Poor; $Y=0$ Non-Poor)

\begin{tabular}{|c|c|c|c|c|}
\hline & Coefficient & $P$ value & Coefficient & $P$ value \\
\hline \multicolumn{5}{|l|}{ Migrant Characteristics } \\
\hline Ln Remittances & -0.288 & 0.000 & -0.300 & 0.000 \\
\hline Duration Overseas & 0.020 & 0.339 & 0.013 & 0.926 \\
\hline Duration Overseas squared & 0.000 & 0.829 & 0.000 & 0.717 \\
\hline Age & -0.014 & 0.049 & -0.018 & 0.019 \\
\hline Females & -0.600 & 0.004 & -0.069 & 0.902 \\
\hline Education & -0.046 & 0.068 & -0.044 & 0.080 \\
\hline Domestic Workers & 0.793 & 0.000 & 0.767 & 0.001 \\
\hline Industrial Workers & 0.156 & 0.468 & 0.191 & 0.402 \\
\hline Country: HongKong & -0.136 & 0.353 & -0.027 & 0.870 \\
\hline Country: Taiwan & 0.186 & 0.222 & 0.339 & 0.065 \\
\hline Country: Saudi Arabia & 0.386 & 0.023 & 0.606 & 0.004 \\
\hline \multicolumn{5}{|l|}{ Household Characteristics } \\
\hline Age of HH Head & 0.014 & 0.002 & 0.013 & 0.004 \\
\hline Education of $\mathrm{HH} \mathrm{Head}$ & -0.026 & 0.165 & -0.027 & 0.154 \\
\hline No. of Dependence & 0.267 & 0.000 & 0.272 & 0.000 \\
\hline HH Head working in agriculture & 0.420 & 0.000 & 0.446 & 0.000 \\
\hline HH Head working in business & 0.105 & 0.415 & 0.138 & 0.293 \\
\hline \multicolumn{5}{|l|}{ Interaction Effect } \\
\hline Ln Remittances * Duration Overseas & & & 0.001 & 0.950 \\
\hline Females * Age & & & -0.020 & 0.155 \\
\hline Females $*$ Taiwan & & & 0.391 & 0.252 \\
\hline Females * Saudi Arabia & & & 0.634 & 0.080 \\
\hline Constant & 3.541 & 0.000 & 3.795 & 0.002 \\
\hline No. of observation & 840 & & 840 & \\
\hline LR chi2 & 131.05 & & 135.72 & \\
\hline Prob > chi2 & 0 & & 0 & \\
\hline Pseudo R2 & 0.1248 & & 0.1292 & \\
\hline
\end{tabular}

Current migrants working in Hongkong, interesting enough, are less likely to be categorised as poor because Hongkong (and also Taiwan) generally offer higher wages for Indonesian workers than other countries (World Bank, 2006). As mentioned by Bachtiar (2011), Indonesian workers who return from East Asian countries, including Hongkong, Korea, and Taiwan, usually come home with significantly more savings. Moreover, Hongkong is the only country that specifies a minimum wage for migrant workers (World Bank, 2006), while Malaysia and Saudi Arabia do not, and while Malaysia is a primary destination for Indonesian migrants, it generally offers the lowest wages. 
Education is an important factor in helping migrants escape poverty. This is indicated by the negative coefficient that education has on poverty status. Age of migrants also has a negative coefficient, suggesting that younger migrants tend to be under the poverty level compared to older migrants. This is probably due to their experience and years spent working overseas. Meanwhile, comparing gender, current households with male migrants tend to be slightly poorer than those with current female migrants, suggesting that potentially, male workers are paid less than female workers. In practice, there are more than double the number of female Indonesian labour migrants than male, with most females working in the domestic sector and males working in the farming and construction sectors.

An examination of household characteristics indicates that the occupation of household head is also important in explaining the welfare of migrant households. Although household heads who work in small business are insignificant, household heads who work in the agriculture sector at home tend to be categorised in poor households. As mentioned before, the agriculture sector in the Malang district tends to be traditional and subsistence, providing a greater probability of being under the poverty line. Moreover, households with more dependents are more likely to live in poverty, possibly because poverty is measured by a per capita basis of expenditure, which suggests there is a higher cost of living for these households. Meanwhile, the result shows no such interaction effects among variables except the positive interaction effect of females current migrants in Saudi Arabia that more likely to be categorized as poor.

Regardless of the motivation for migration, addressing remittances in a productive way is the good strategy for the long-term sustainability of returned migrants in Malang. If macroeconomic policies are in favour of saving and investment, one can expect higher savings and investments in Malang, and this will raise the physical capital per worker. Another possibility is to impose a regulatory regime where small and medium enterprises can be promoted and job opportunities are offered to returned migrants. Providing opportunities to utilise the skills that migrants learned overseas is useful for both migrants and country. In order to avoid lost opportunities, government and the local bodies should implement strategies that will benefit returned migrants and Malang.

\section{Conclusions}

This paper has focused on the sustainable conditions amongst returning migrant households in Indonesia. Previous literature mainly focused on the present condition of current migrant households mainly due to a lack of historical data. One can see the question of sustainability becoming an emerging issue in Asia following the tendencies of accepting skilled migrants for short-term contracts by ASEAN member countries and East Asian countries. This paper, therefore, recommends that historical data be collected in future, and turns a small stone in this direction by using survey data from Malang. This study is limited by the small number of proxies available and the small number of observations in our sample which precludes a more conclusive statistical analysis.

The one conclusion that this paper reached is that while remittances reduce the probability of households at home living in poverty, returning migrant households will not better off for very long, and will almost certainly return to poverty after a period of time. This is because their accumulated assets and savings are mostly used for consumption, they are not utilised to assess for sustainable and productive ventures such as business because they are not the priority of migrant households. The limitation in this regard is that the paper focuses only on the financial capital contributed to the welfare of return migrant households, not incorporating the possible human capital, business skills, or attitude that migrants get from staying overseas. 
By policy implication, there is a need for government to provide guidance to migrant households on how to use their income in more sustainable and productive activities in order to make the best of their available financial capital. This is important to bring households out of poverty in the long term. Some sectors with the potential for development such as small and medium enterprises should be related to the local potential of Malang district where the migrants come from. The opportunities for developing SMEs still exist, especially considering the strategic location of the Malang district in the middle of East Java and the growing creative economy in Indonesia.

However, not all return migrants are interested in business or self-employment, which means that programs facilitating returning migrants to enter the formal labour market or as paid employees are also limited. The formal sector is difficult because it usually requires nonfinancial capital, such as human capital and social capital. A comprehensive development of financial and non-financial capital is therefore needed as a local government policy concern.

\section{Acknowledgement}

We acknowledge the financial support from the Indonesia Project Research Grant 2015-16 of Australian National University (ANU) and SMERU Research Institute to carry out this research.

\section{References}

Acosta, P., Calderon, C., Fajnzylber, P., Lopez, H. (2008). What is the Impact of International Remittances on Poverty and Inequality in Latin America? World Development, 36(1), 89-114.

Adams, Jr. R. H., Cuecuecha, A., Page, J. (2008). Remittances, Consumption and Investment in Ghana. World Bank Policy Research Working Paper Series.

Adams, Jr. R. H., Cuecuecha, A. (2010). The Economic Impact of International Remittances on Poverty and Household Consumption and Investment in Indonesia. World Bank Policy Research Working Paper Series.

Adams, R. H., Cuecuecha, A. (2010). Remittances, Household Expenditure and Investment in Guatemala. World Development, 38(11), 1626-1641.

Adams, R. H., Page, J. (2005). Do International Migration and Remittances Reduce Poverty in Developing Countries? World Development, 33(10), 1645-1669.

Bachtiar, P. P (2011). Migration Outflow and Remittance Patterns in Indonesia: National as well as Subnational Perspectives. Philippine Journal of Development, 38(1-2), 27-54.

BNP2TKI (2018). Data Penempatan dan Perlindungan TKI Periode Bulan Desember Tahun 2017. Badan nasional Penempatan dan Perlindungan tenaga Kerja Indonesia. Jakarta. Indonesia.

BPS (2017). Statistik Mobilitas Penduduk dan Tenaga Kerja. Badan Pusat Statistik. Jakarta. Indonesia.

Grigorian, D. A., Melkonyan, T. A. (2011). Destined to receive: The Impact of Remittances on Household Decisions in Armenia. Review of development economics, 15(1), 139153.

Hugo, G. (1995). International Labor Migration and the Family: Some Observations from Indonesia. Asian and Pacific Migration Journal, 4(2-3), 273-301.

Hugo, G. (2002). Effects of International Migration on the Family in Indonesia. Asian and Pacific Migration Journal, 11(1), 13-46. 
León-Ledesma, M., Piracha, M. (2001). International Migration and the Role of Remittances in Eastern Europe. University of Kent, Department of Economics. Discussion Paper 01, 13.

Nguyen, T., Purnamasari, R. (2011). Impacts of International Migration and Remittances on Child Outcomes and Labor Supply in Indonesia: How does Gender Matter? World Bank Policy Research Working Paper Series.

Parinduri, R. A., Thangavelu, S. M. (2011). Impact of Remittances on Human Capital Development of Children in Indonesian Household.

Raharto, A. (2011). The Migratory Experience of Returned Migrant Domestic Workers: The Example of Indonesia. In: Paper on Workshop on Strengthening Dialogue between ESCWA and ESCAP Countries on International Migration and Development.

Schiopu, I., Siegfried, N. (2006). Determinants of workers' remittances. Evidence from the European neighbouring region', European Central Bank Discussion Paper No. 688. SMERU (2015). Return Migration and the Importance of Reintegration Policies. Policy Brief. No. 3/2015

Syafitri, W., Knerr, B. (2012). Migration in East Java, Indonesia: Implications for Family Welfare and Rural Development. International Labor Migration International Labor Migration, 92.

Veall, M. R., Zimmermann, K. F. (1996). Pseudo-R2 Measures For Some Common Limited Dependent Variable Models. Journal of Economic surveys, 10(3), 241-259.

Yang, D., Martínez, A. (2005). Remittances and Poverty in Migrants' Home Areas: Evidence from the Philippines.

Yen, K. C., Platt, M., Yeoh, B. S., Mila, S., Arlini, G. B., Sugiyarto, E. (2014). Gendered Migration Patterns, Processes and Outcomes: Results from a Household Survey in Ponorogo, Indonesia.

Wahba, J. (2015). Who Benefits from Return Migration to Developing Countries? IZA World of Labor 2015, 123 (doi: 10.15185/izawol.123), pp. 1 - 1 o.

World Bank Group (2015). World Bank Publications. 